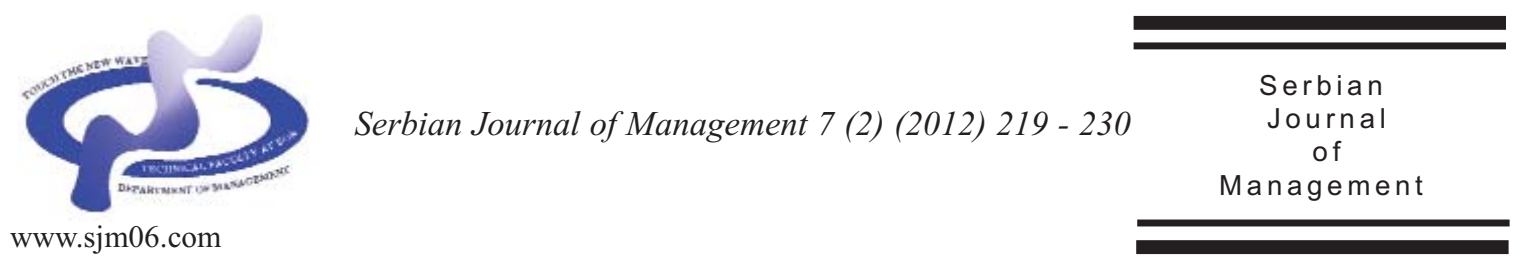

\title{
THE MEASUREMENT OF SERVICE QUALITY WITH SERVQUAL FOR DIFFERENT DOMESTIC AIRLINE FIRMS IN TURKEY
}

\author{
Kenan Aydin ${ }^{*}$ and Seda Yildirimb

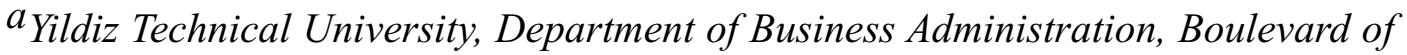 \\ Barbaros, Yildiz Campus, Yildiz-Besiktas (post code: 34349), Turkey

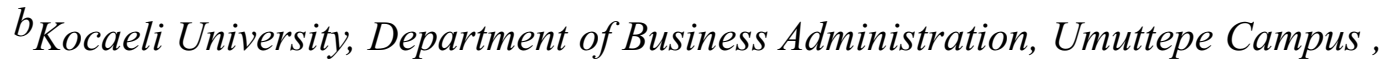 \\ Kocaeli (post code:41380), Turkey
}

(Received 26 December 2011; accepted 29 August 2012)

\begin{abstract}
The primary purpose of this research is to determine whether there is a significant difference between the passengers' service quality expectations and service quality perceptions in different airline firms. The collateral purpose is to find out whether there is a significant difference between service quality expectation and service quality perception of the passengers who have different socio-demographic characteristics. To achieve these purposes, the 5 -dimensional scale, suggested by Parasuraman et.al (1988) was applied to the airline travel sector. The questionnaire was used in interviewing the passengers at Sabiha Gökçen Airport in Istanbul in Turkey with a "face to face" method. The data was analysed in SPSS 16 program after questionnnaires were collected. Firstly, the demographic characteristics of passengers were presented for different airline firms. Then the highest and the lowest gaps for the each statement was determined. Lastly it was compared if there was a significant difference between the service quality expectation and perception for different domestic airline firms.
\end{abstract}

Keywords: Service Quality, Airlines, SERVQUAL

\section{INTRODUCTION}

In the competing world, all businesses can provide "the same types of service-airline transportation, tax-return preparation, shampoo and blow dry services" but the difference can be provided by customers.
Because they seperate the quality of services, "competing service businesses may look alike, but they do not feel alike" (Berry et al., 1988). Delivering high-quality service to customers is the key strategy to survive in today's competitive service industries such as airline transportation services (Zeithaml et

\footnotetext{
* Corresponding author: kenanaydin@gmail.com
}

DOI: $10.5937 /$ sjm 7-1317 
al., 1996). Service quality conditions influences a firm's competitive advantage by retaining customer patronage, and with this comes market share, and ultimately profitability (Park et al., 2004). Because of that, airlines need to understand passengers' needs and expectations. In practice, most airlines measure passenger perceptions of their service offerings to understand the company's performance levels, without having clear knowledge of passenger expectations for service.

Lack of understanding or misunderstanding of such expectations could pose serious problems in resource allocation decisions. Therefore, it is an imperative for airline management to determine what their customers want and do not want (Chen \& Chang, 2005).

The expectations construct has been viewed as playing a key role in consumer evaluation of service quality Its meaning in the service quality literature is similar to the ideal standard in the consumer satisfaction/dissatisfaction literature (Gilbert \& Wong, 2003). Passengers' expectations are among the factors influencing the service decisions of airlines. Empirical evidence has indicated that success in customer-focused service development requires a deep understanding of customer needs, expectations, and preferences and that marketing strategies implemented by airlines to expand internationally must take into account the different expectations and perceptions of passengers (Aksoy et al., 2003).

A number of studies in Turkey have reported results of service quality measurement of THY (Turkish Air Lines) (Aksoy et al., 2003; Pakdil \& Aydın, 2007). There is not enough useful information or reseach about service quality of other domestic airline firms. This study differs from earlier service quality studies in Turkey because in this study, it's tried to find out the service quality of both THY and other domestic airline firms. With SERVQUAL, passengers'expectations and perceptions in airline services was assesed. Also the survey includes some demographics of passengers that can effect the expectations and perception of airline service quality.

\section{AIRLINE SERVICE QUALITY}

Service quality is a composite of various interactions between customers and airlines, with employees seeking to influence customers' perceptions and the image of the carriers (Gursoy et al., 2005; Ishaq, 2012). Service quality is a measure of how well the service level delivered matches customer expectations. Delivering quality service means conforming to customer expectations on a consistent basis (Parasuraman et al., 1985). In 1988 Parasuraman, Zeithaml and Berry developed a generic instrument called SERVQUAL to measure service quality based on input from focus groups. It consists of five factors (tangibles, reliability, responsiveness, assurance and empathy) and contains a two-part, 22 scale items regarding expectations and performance. These five factors have been tested through numerous empirical studies in so various industries by many researchers (An \& Noh, 2009) that it is also used in a variety of organizational settings, including libraries and information centers (Landrum et al., 2009).

The SERVQUAL has been one of the most widely used and applied scales for the measurement of perceived service quality in recent years (Bigne et al., 2003). Gronroos (1993) suggested that measuring passenger 
experiences in airline service quality is a theoretically valid way of measuring perceived quality. This led to the use of survey questionnaires to collect data for analysis (Liou et al., 2010). A number of studies have addressed service quality issues.

The mainstream research has been based on the notion that quality of service is perceived and evaluated by customers (Liou $\&$ Tzeng, 2007). Measuring expectations and perceptions separately also leads to better understanding of the Dynamics of customers' assesment of service quality over time. For example, if SERVQUAL scores for certain items have declined significantly form one period to another, managers can assess whether this is due to higher expectations, lower perceptions, or both. This information is not available when perceptions relative to expectations are measured on the same scale (Parasuraman \& Berry, 1993).

Most of the previous SERVQUAL-based empirical studies of airline service quality were performed on the basis of the respondents' mean scores built on Likert scaling. The categories in ordinal scales are ranked through their properties. As it is a ranking, frequencies or percentages are more appropriate statistics than means and standard deviations for meaningful interpretations. If means or standard deviations are preferred, passengers' raw scores should be transformed into quantitative intervalscores. To perform this transformation, factor loadings produced through factor analysis might be used as an alternative tool. In factor analysis, "a factor load on an observed variable is conceptualized as a properly weighted and summed combination of the scores on factors that underlie it" (Pakdil \& Aydın, 2007).

\section{RESEARCH METHODOLOGY}

Questionnaire which was based on the previous literature research, makes it much more practical to be answered by participants, was developed. Firstly, the demographics as gender (sex), age, income, educational level, marital status, purpose of airline trip and flying frequency were determined. Then, the service quality dimensions (SERVQUAL) were taken into consideration under the inspiration of the previous studies. Even though SERVQUAL presents general quality dimensions for service industries, it does not include specific dimensions for each service sector. Questions aiming to address expectations and perceptions were rated using 5-point Likert scale. The scale in both cases was from 1- strongly unimportant to 5- strongly important. The most useful SERVQUAL's service quality dimensions which includes 22-items, weere used. These items are as follows:

- $\quad$ Tangibles

- Q1: Modern looking equipment

- Q2: Physical facilities

- Q3: Employees good-looking

- Q4: Materials

- Reliability

- Q5: Promise to do something by a certain time

- Q6: A sincere interest in solving customer's problem

- Q7: Perform the service right the first time

- Q8: Provide the service at the time of promised

- Q9: Insist on error free records 
- Responsiveness

- Q10: Employees tells customers exactly when services will be performed

- Q11: Employees will give prompt service to customer

- Q12: Employees will always be willing to help customers

- Q13: Employees will never be too busy to respond to customers' requests.

- Assurance

- Q14: The behavior of employees will instill confidence in customers

- Q15: Customers will feel safe in transactions

- Q16: Employees will consistently courteous with customers

- Q17: Employees will have the knowledge to answer customers' questions

\section{- Empathy} attention

- Q18: Give customers individual

- Q19: Operating hours convenient to all their customers

- Q20: Employees give customers personal attention

- Q21: Have customer's best interests at heart

- Q22: Understand the specific needs of customers

This study was conducted on a sample of travellers at Sabiha Gökçen Airport on 5th March 2010 from 13:00 pm to 15:00 pm at . The Sabiha Gökçen Airport in Istanbul, Turkey was chosen because as a developing company, by the year of 2009 it had over 6 million passengers. We used the "convenience sampling method" because it was not possible to reach the population. In total 140 passengers were interviewed but 29 of them were not suitable for analysis. The questionnaires were handed to passengers waiting at the boarding gates and the exit point of the airport. We included both the incoming and outgoing passengers for the sample. Upon completion, the forms were collected. Then collected data were analyzed by SPSS 16.0 and THY and other domestic airlines (Onurair, Atlasjet, Pegasus air, Sunexpress air) were compared in the terms of SERVQUAL scores.

\section{RESULTS}

\subsection{Demographic Results}

Passengers were classified according to their gender (sex), age, marital status, education, income, travel purpose, travel frequency and flight counts. Also it was tried to find out which factors were more crucial for choosing an airline firm (Table 1). THY and other domestic airline firms were presented seperately to see the demograpic differences.

As presented in Table 1, 63.5\% of THY's passengers were female and $62.5 \%$ of other domestic airlines' passengers were male. The age group of 18-24 preferred both THY and other domestic airlines nearly in a same percent of their total size. 69.8 percent of THZY passengers had an university degree and $63.5 \%$ traveled for holiday. Passengers from other domestic airlines used air transport largely for holiday purposes as THY passengers and most of them were single (64.6\%). Also, the age group (35-44) mostly preferred THY. Besides that, young ages' (18-24) preferences were not different for different airline firms, almostly they were 
Table 1. Demographics of Passengers $(N=111)$

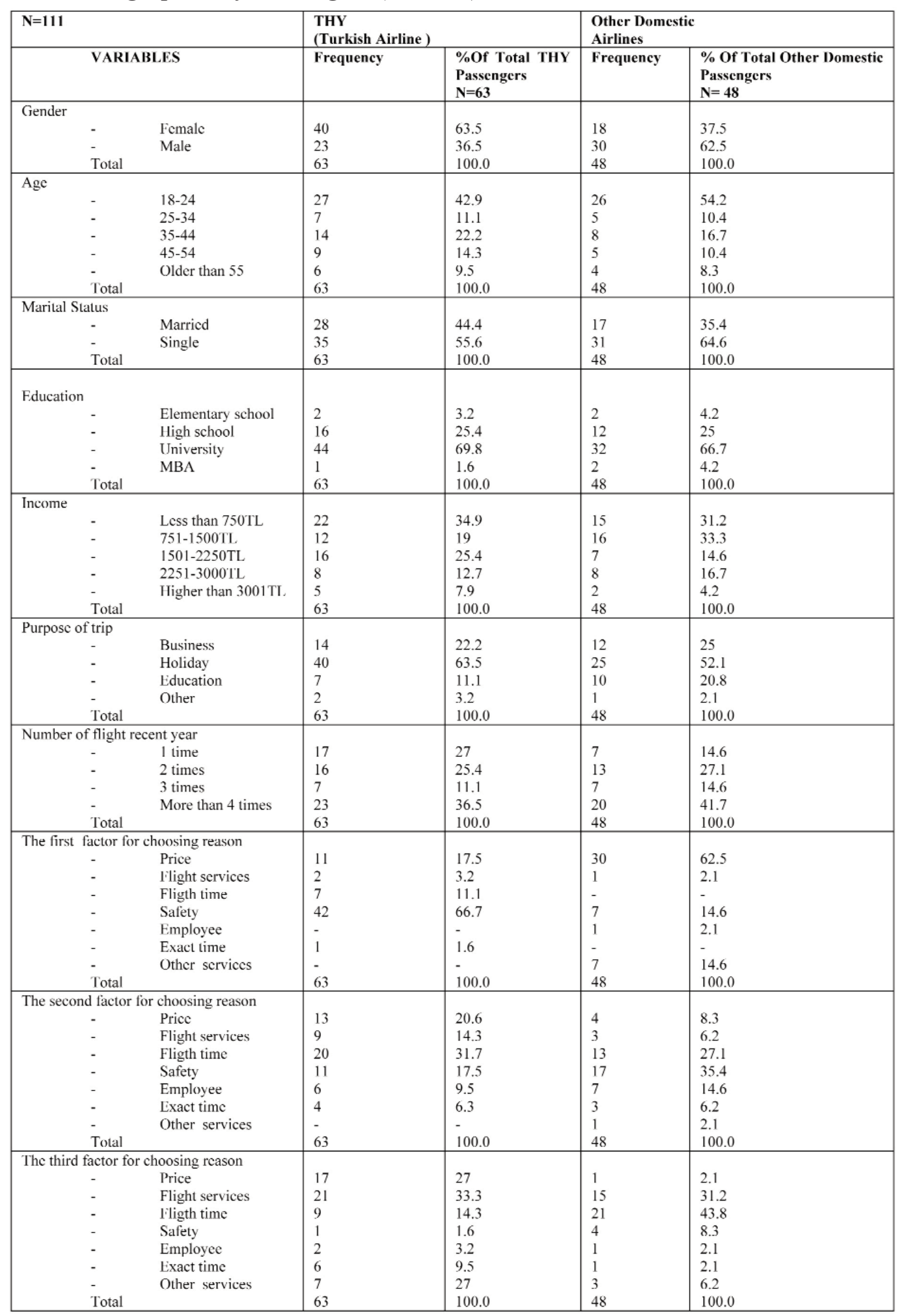


same percent of their total. First time flyers and more than 4 times flyers preferred THY (27\% and $36.5 \%)$. In other domestic airlines, 2 times flyers and more than 4 times flyers preferred $(27.1 \%$ and $41.7 \%)$. There was no significant difference in passengers'income and education for both of THY and other domestic airlines. But in choosing airline, there were some differences in the factors that were decisive. Especially, the most important factor for choosing airline was safety $(66.7 \%)$ in THY, on the other side the the most important factorfor choosing airline was price $(62.5 \%)$ in other domestic airlines. The second one was flight time $(31.7 \%)$ in THY and in other domestic firms it was safety (35.4\%). Thirdly, the fligth services were found important for THY's passengers (33.3\%) and the flight time was important for other domestic airlines (43.8\%).To find out whether there was a relationship between passengers' demographics and airline firm preference, Chi-Square test was used in this study. In table 2 Pearson Chi-Square results of demographics were given.

There wasn't significant relationship between demographics and airline firm preference. Some of the limitations of this study were that the the sample size was small and the implementation time was short. The results can be varied in different airline firm preferences.

Table 2. Chi-Square Results of Demographics and Airline Firm Preference

\begin{tabular}{|l|l|l|l|}
\hline Demographic Variables & Value & df & $\begin{array}{l}\text { Asymp. } \\
\text { Sig.(2-sided) }\end{array}$ \\
\hline Marital Status & 6.118 & 4 & 0.191 \\
\hline Sex & 9.877 & 4 & 0.43 \\
\hline Age & 16.120 & 16 & 0.445 \\
\hline Income & 16.205 & 16 & 0.439 \\
\hline Education & 8.158 & 12 & 0.773 \\
\hline
\end{tabular}

(*Indicates significance level $<0,01$ )
As shown in Table 3, THY's passengers prefered airline firm according to its safety degree at first and other airline firms' passengers prefered their airline firm according to its price. In table 4, the relationship between airline services preference and airline firm preference according to Pearson Chi-Square values.

First preference of travel purpose of passengers was found to be with significant $p$ value $(p=0.001<0.01)$ and it can be said that there was a significant relationship between travel purpose and airline firm preference. Also third preference gave a result with a significant $p$ value $(p=0.007<0.01)$. Second preference didn't give a significant result ( $p$ $=0.171>0.01)$. THY's passengers preferred safety as their first preference while passengers of other domestic airline firms' preferred price.

\subsection{Reliability Results}

In this study, Cronbach's Alpha values were used to determine both of passengers' exceptions and perceptions about airline services. Firstly, for expectation-related items' Cronbach's Alpha value was 0.835 and for perception-related items' Cronbach's Alpha value was 0.880 (Table 5). The internal consistency of both expectations and perceptions were analyzed with Cronbach's Alpha and the results were satisfactorily. Also, 5 main dimensions of service quality's Cronbach Alpha values were analyzed. For expectations part of the questionnaire, Cronbach's Alpha was found to be 0.728 for Tangibles, 0.837 for Reliability, 0.684 for Responsiveness, 0.540 for Assurance and 0.666 for Empathy. For perceptions part of the questionnaire, Cronbach's Alpha was found to be 0.800 for Tangibles, 0.844 for Reliability, 0.384 for Responsiveness, 0.814 
for Assurance and 0.760 for Empathy (Table $6)$.

\subsection{Results of Expectations and Perceptions}

It was preferred to present THY's and other domestic airline firms' SERVQUAL results seperately, in this study, because there was a great difference between obtained results. Table 7 shows that the gap between perceptions and expectations of service quality dimensions is smaller in Turkish Airlines than the other domestic airline firms.

In THY, passengers' expectations and perceptions have similar results in general. But in other domestic airline firms, there is a different result. "Reliability", "Responsiveness" and "Assurance" dimensions have a big gap between expectations and perceptions in other domestic airline firms. "Tangibles" and "Empathy" dimesions have less differences between expectations and perceptions.

Descriptive Statistics was not enough to say that there was a significant gap between expectations and perceptions. That's why one-way ANOVA test was used to determine the significance in differences. Table 8 shows that there is a significant gap between

Table 3. Crosstabulation of Airline firm Preferences and Airline Service Preferences

\begin{tabular}{|l|l|l|l|l|l|l|l|}
\hline \multirow{2}{*}{ Airline Firm } & \multicolumn{2}{|l|}{ Airline Service Preferences } \\
\cline { 2 - 9 } & $\begin{array}{l}\text { In-Flight } \\
\text { services }\end{array}$ & $\begin{array}{l}\text { Flight } \\
\text { time }\end{array}$ & $\begin{array}{l}\text { Safety of } \\
\text { Flight }\end{array}$ & On time & Employee & Price & Total \\
\hline THY & 2 & 7 & 42 & 1 & 0 & 11 & 63 \\
& $\% 1.8$ & $\% 6.3$ & $\% 37.8$ & $\% 0.9$ & $\% 0$ & $\% 9.9$ & $\% 56.8$ \\
\hline Onurair & 1 & 0 & 9 & 1 & 0 & 13 & 24 \\
& $\% 0.9$ & $\% 0$ & $\% 8.1$ & $\% 0.9$ & $\% 0$ & $\% 11.7$ & $\% 21.6$ \\
\hline Atlas & 0 & 0 & 2 & 0 & 1 & 6 & 9 \\
& $\% 0$ & $\% 0$ & $\% 1.8$ & $\% 0$ & $\% 0.9$ & $\% 5.4$ & $\% 8.1$ \\
\hline Pegasus & 0 & 0 & 1 & 0 & 0 & 5 & 6 \\
& $\% 0$ & $\% 0$ & $\% 0.9$ & $\% 0$ & $\% 0$ & $\% 4.5$ & $\% 5.4$ \\
\hline Others & 0 & 0 & 2 & 1 & 0 & 6 & 9 \\
& $\% 0$ & $\% 0$ & $\% 1.8$ & $\% 0.9$ & $\% 0$ & $\% 5.4$ & $\% 8.1$ \\
\hline Total & 3 & 7 & 56 & 3 & 1 & 41 & 111 \\
& $\% 2.7$ & $\% 6.3$ & $\% 50.5$ & $\% 2.7$ & $\% 0.9$ & $\% 36.9$ & $\% 100.0$ \\
\end{tabular}

Table 4. Chi-Square Results of Airline Services Preference and Airline Firm Preference

\begin{tabular}{|l|l|l|l|}
\hline Preferences & Value & df & $\begin{array}{l}\text { Asymp. } \\
\text { Sig.(2-sided) }\end{array}$ \\
\hline First Prefer & 45.282 & 20 & $0.001^{*}$ \\
\hline Second Prefer & 32.428 & 24 & 0.171 \\
\hline Third Prefer & 44.105 & 24 & $0.007^{*}$ \\
\hline
\end{tabular}

(*Indicates significance level $<0,01$ )

Table 5. Reliability Test Results of Expectations and Perceptions

\begin{tabular}{|l|l|l|l|}
\hline & N & $\begin{array}{l}\text { N of } \\
\text { Items }\end{array}$ & $\begin{array}{l}\text { Cronbach's } \\
\text { Alpha }\end{array}$ \\
\hline Expectations of passengers & 111 & 22 & 0.835 \\
\hline Perceptions of passengers & 111 & 22 & 0.880 \\
\hline
\end{tabular}


Table 6. Reliability Results for Service Quality Dimensions

\begin{tabular}{|l|l|l|l|l|}
\hline Dimensions & $\mathrm{N}$ & $\mathrm{N}$ of Items & $\begin{array}{l}\text { Cronbach's Alpha } \\
\text { (Expectation) }\end{array}$ & $\begin{array}{l}\text { Cronbach's Alpha } \\
\text { (Perception) }\end{array}$ \\
\hline Tangibles & 111 & 5 & 0.728 & 0.800 \\
\hline Reliability & 111 & 4 & 0.837 & 0.844 \\
\hline Responsiveness & 111 & 4 & 0.684 & 0.384 \\
\hline Assurance & 111 & 4 & 0.540 & 0.814 \\
\hline Empathy & 111 & 5 & 0.666 & 0.760 \\
\hline
\end{tabular}

perceptions and expectations in both THY and other domestic airline firms.

Q1 (Modern looking equipment) has the significant difference between perception and expectation in THY. In other domestic airline firms, all of tangibles'dimensions have the significant difference between perceptions and expectations. Q1, Q2, Q3 and Q4 were found to be with significant $\mathrm{p}$ value $(\mathrm{p}=0.000<0.05)$. For $\mathrm{Q} 5(\mathrm{p}=$ $0.004<0.05), Q 6(\mathrm{p}=0.004<0.05), \mathrm{Q} 7(\mathrm{p}=$ $0.000<0.05), Q 8(\mathrm{p}=0.000<0.05)$ and Q9 $(\mathrm{p}$ $=0.000<0.05)$ were found to be significant with the level $(<0.05)$. For THY and other domestic airline firms all of the $p$ values were found as a significant $(\mathrm{p}=0.000<0.05)$.

Table 7. Descriptive Statistics

\begin{tabular}{|c|c|c|c|c|c|c|c|c|}
\hline & \multicolumn{4}{|c|}{ THY } & \multicolumn{4}{|c|}{ Other Airline Firms } \\
\hline & \multicolumn{2}{|c|}{ Expectations } & \multirow{2}{*}{$\begin{array}{l}\text { Perceptions } \\
\text { Mean }\end{array}$} & \multirow[t]{2}{*}{ Gaps } & \multicolumn{2}{|c|}{ Expectations } & \multirow{2}{*}{$\begin{array}{l}\text { Perceptions } \\
\text { Mean }\end{array}$} & \multirow[t]{2}{*}{ Gaps } \\
\hline & $\mathrm{N}$ & Mean & & & $\mathrm{N}$ & Mean & & \\
\hline \begin{tabular}{cc}
\multicolumn{2}{l}{ Tangibles } \\
- & Q1 \\
- & Q2 \\
- & Q3 \\
- & Q4
\end{tabular} & 63 & $\begin{array}{l}4.77 \\
4.12 \\
4.66 \\
3.71 \\
\end{array}$ & $\begin{array}{l}4.25 \\
3.90 \\
4.58 \\
3.61 \\
\end{array}$ & $\begin{array}{l}-0.52 \\
-0.22 \\
-0.08 \\
-0.10\end{array}$ & 48 & $\begin{array}{l}4.62 \\
4.14 \\
4.58 \\
3.81 \\
\end{array}$ & $\begin{array}{l}3.37 \\
3.06 \\
3.89 \\
2.91 \\
\end{array}$ & $\begin{array}{l}-1.25 \\
-1.08 \\
-0.69 \\
-0.90 \\
\end{array}$ \\
\hline \begin{tabular}{cc}
\multicolumn{2}{l}{ Reliability } \\
$-\quad$ Q5 \\
$-\quad$ Q6 \\
$-\quad$ Q7 \\
$-\quad$ Q8 \\
$-\quad$ Q9
\end{tabular} & 63 & $\begin{array}{l}4.65 \\
4.53 \\
4.82 \\
4.74 \\
4.77\end{array}$ & $\begin{array}{l}4.25 \\
4.06 \\
4.38 \\
4.26 \\
4.31\end{array}$ & $\begin{array}{l}-0.40 \\
-0.47 \\
-0.44 \\
-0.48 \\
-0.46 \\
\end{array}$ & 48 & $\begin{array}{l}4.60 \\
4.47 \\
4.75 \\
4.79 \\
4.70\end{array}$ & $\begin{array}{l}3.35 \\
3.41 \\
3.54 \\
3.31 \\
3.66\end{array}$ & $\begin{array}{l}-1.25 \\
-1.06 \\
-1.21 \\
-1.11 \\
-1.04 \\
\end{array}$ \\
\hline $\begin{array}{cc}\text { Responsiveness } \\
- & \text { Q10 } \\
- & \text { Q11 } \\
\text { - } & \text { Q12 } \\
- & \text { Q13 } \\
\end{array}$ & 63 & $\begin{array}{l}4.20 \\
4.50 \\
4.60 \\
3.41 \\
\end{array}$ & $\begin{array}{l}3.92 \\
4.01 \\
4.50 \\
3.49 \\
\end{array}$ & $\begin{array}{r}-0.28 \\
-0.49 \\
-0.10 \\
0.08 \\
\end{array}$ & 48 & $\begin{array}{l}4.22 \\
4.41 \\
4.42 \\
3.52 \\
\end{array}$ & $\begin{array}{l}3.22 \\
3.22 \\
3.27 \\
3.06 \\
\end{array}$ & $\begin{array}{l}-1.00 \\
-1.19 \\
-1.15 \\
-0.46 \\
\end{array}$ \\
\hline $\begin{array}{cc}\text { Assurance } \\
- & \text { Q14 } \\
- & \text { Q15 } \\
- & \text { Q16 } \\
- & \text { Q17 } \\
\end{array}$ & 63 & $\begin{array}{l}4.69 \\
4.65 \\
4.71 \\
4.60 \\
\end{array}$ & $\begin{array}{l}4.26 \\
4.12 \\
4.25 \\
4.07 \\
\end{array}$ & $\begin{array}{l}-0.43 \\
-0.53 \\
-0.46 \\
-0.53\end{array}$ & 48 & $\begin{array}{l}4.56 \\
4.58 \\
4.66 \\
4.47\end{array}$ & $\begin{array}{l}3.60 \\
3.52 \\
3.56 \\
3.39\end{array}$ & $\begin{array}{l}-0.96 \\
-1.06 \\
-1.10 \\
-1.08\end{array}$ \\
\hline $\begin{array}{cc}\text { Empathy } & \\
- & \text { Q18 } \\
- & \text { Q19 } \\
- & \text { Q20 } \\
- & \text { Q21 } \\
- & \text { Q22 }\end{array}$ & 63 & $\begin{array}{l}3.49 \\
3.49 \\
3.28 \\
3.46 \\
3.77\end{array}$ & $\begin{array}{l}3.36 \\
3.36 \\
3.17 \\
3.44 \\
3.65\end{array}$ & $\begin{array}{l}-0.13 \\
-0.13 \\
-0.11 \\
-0.02 \\
-0.12\end{array}$ & 48 & $\begin{array}{l}3.31 \\
3.64 \\
3.22 \\
3.27 \\
4.06\end{array}$ & $\begin{array}{l}2.72 \\
3.27 \\
2.89 \\
3.10 \\
3.58\end{array}$ & $\begin{array}{l}-0.59 \\
-0.37 \\
-0.33 \\
-0.17 \\
-0.48\end{array}$ \\
\hline
\end{tabular}


Table 8. One-Way ANOVA Test Results

\begin{tabular}{|c|c|c|c|c|c|c|}
\hline & TANGIBLES & $\mathbf{F}$ & Sig. & & $\mathbf{F}$ & Sig. \\
\hline \multirow{26}{*}{ THY } & $\begin{array}{l}\text { Q1: Modern looking } \\
\text { equipment }\end{array}$ & 20.944 & $0.000 *$ & \multirow{26}{*}{$\begin{array}{l}\text { OTHER } \\
\text { DOMESTIC } \\
\text { AIRLINE } \\
\text { FIRMS }\end{array}$} & 58.264 & $0.000^{*}$ \\
\hline & Q2:Physical Facilities & 2.460 & 0.119 & & 25.758 & $0.000^{*}$ \\
\hline & Q3:Employees good-looking & 0.569 & 0.452 & & 17.729 & $0.000^{*}$ \\
\hline & Q4:Materials & 0.335 & 0.564 & & 16.314 & $0.000^{*}$ \\
\hline & RELIABILITY & & & & & \\
\hline & $\begin{array}{l}\text { Q5: Promise to do something } \\
\text { by a certain time }\end{array}$ & 8.513 & $0.004 *$ & & 38.968 & $0.000^{*}$ \\
\hline & $\begin{array}{l}\text { Q6: A sincere interest in } \\
\text { solving customer's problem }\end{array}$ & 8.735 & $0.004 *$ & & 33.668 & $0.000^{*}$ \\
\hline & $\begin{array}{l}\text { Q7: Perform the service right } \\
\text { the first time }\end{array}$ & 17.358 & $0.000^{*}$ & & 45.174 & $0.000^{*}$ \\
\hline & $\begin{array}{l}\text { Q8: Provide the service at the } \\
\text { time of promised }\end{array}$ & 16.297 & $0.000^{*}$ & & 51.294 & $0.000^{*}$ \\
\hline & $\begin{array}{l}\text { Q9: Insist on error free } \\
\text { records }\end{array}$ & 17.051 & $0.000 *$ & & 35.693 & $0.000 *$ \\
\hline & RESPONSIVENESS & & & & & \\
\hline & $\begin{array}{l}\text { Q10: Employees tells } \\
\text { customers exactly when } \\
\text { services will be performed }\end{array}$ & 2.473 & 0.118 & & 18.348 & $0.000 *$ \\
\hline & $\begin{array}{l}\text { Q11: Employees will give } \\
\text { prompt service to customer }\end{array}$ & 9.777 & $0.002 *$ & & 39.694 & $0.000 *$ \\
\hline & $\begin{array}{l}\text { Q12: Employees will always } \\
\text { be willing to help customers }\end{array}$ & 0.045 & 0.832 & & 36.502 & $0.000^{*}$ \\
\hline & $\begin{array}{l}\text { Q13: Employees will never be } \\
\text { too busy to respond to } \\
\text { customers' requests. }\end{array}$ & 0.095 & 0.758 & & 3.798 & 0.054 \\
\hline & ASSURANCE & & & & & \\
\hline & $\begin{array}{l}\text { Q14: The behavior of } \\
\text { employees will instill } \\
\text { confidence in customers }\end{array}$ & 10.600 & $0.001 *$ & & 29.901 & $0.000^{*}$ \\
\hline & $\begin{array}{l}\text { Q15: Customers will feel safe } \\
\text { in transactions }\end{array}$ & 10.882 & $0.001 *$ & & 45.768 & $0.000^{*}$ \\
\hline & $\begin{array}{ll}\text { Q16: Employees } & \text { will } \\
\text { consistently courteous } & \text { with } \\
\text { customers }\end{array}$ & 11.066 & $0.001 *$ & & 48.699 & $0.000 *$ \\
\hline & $\begin{array}{l}\text { Q17: Employees will have the } \\
\text { knowledge to answer } \\
\text { customers' questions }\end{array}$ & 17.375 & $0.000 *$ & & 30.982 & $0.000 *$ \\
\hline & EMPATHY & & & & & \\
\hline & $\begin{array}{l}\text { Q18: Give customers } \\
\text { individual attention }\end{array}$ & 0.438 & 0.509 & & 5.051 & $0.027^{*}$ \\
\hline & $\begin{array}{l}\text { Q19: Operating } \\
\begin{array}{l}\text { convenient to hours } \\
\text { customers }\end{array}\end{array}$ & 0.458 & 0.500 & & 2.470 & 0.119 \\
\hline & $\begin{array}{l}\text { Q20: Employees give } \\
\text { customers personal attention }\end{array}$ & 0.365 & 0.547 & & 1.944 & 0.167 \\
\hline & $\begin{array}{l}\text { Q21: Have customer's best } \\
\text { interests at heart }\end{array}$ & 0.006 & 0.937 & & 0.435 & 0.511 \\
\hline & $\begin{array}{l}\text { Q22: Understand the specific } \\
\text { needs of customers }\end{array}$ & 0.300 & 0.585 & & 5.482 & $0.021 *$ \\
\hline
\end{tabular}

(*Indicates significance level $<0.05$ )

In responsiveness dimension, Q11 ( $\mathrm{p}=$ significant in both THY and other domestic $0.002<0.05)$ was found as a significant in airline firms. Finally, only in other domestic THY. Q10, Q11 and Q12 were found airline firms, there a significant $\mathrm{p}$ value for significant in other domestic airline firms. Q18 $(\mathrm{p}=0.027<0.05)$ and $\mathrm{Q} 22(\mathrm{p}=$ Q14, Q15, Q16 and Q17 were found to be $0.021<0.05)$ was found. According to these 
results it can be said that there was a significant differences between passengers' expectations and perceptions in other domestic airline firms for tangibles, reliability, responsiveness, assurance and empathy dimension.

\section{CONCLUSIONS}

In Turkey, the airline service industry is a developing sector since the year 2000. Profile of passengers has been changed into varied demographics, meaning that all classes of passengers and not only ones with high income can use airline services. According to these changes, airline services sector has increasex competition and this competition is forcing the representatives of the airline businesses to understand passengers' expectations and perceptions better.

In this study, findings are based on data collected from THY and other domestic airline firms (such are Onur air, Atlasjet, Pegasus, etc). The existance of any significant differences between expectations and perceptions in airline services of different airline firms was investigated. The study included 5 service quality dimensions: Tangibles, Reliability, Responsiveness, Assurance and Empathy.

There wasn't found any significant relationship between demographics and airline firm preferences. Airline firms preferences were found to be varied in different groups. The passengers were asked to rate their first "three airline preferences". According to Pearson Chi-Square test results, a significant relationship between airline firms preference and airline services preference was found. Especially, first airline service preference among the passengers had important difference. For
THY passengers, "safety" factor was found to be the most important to prefer this airline company. For other domestic airline firms, "price" was found to be the most important factor to prefer those airline companies.

Reliability of theobtained results was tested using the Cronbach's Alpha values for both the passengers' expectations and perceptions. The results revealed high enoung Cronbach's Alpha values to claim that the scale was reliable. Also all of the SERVQUAL dimension were tested seperately and It was seen that "Tangibles, Reliability, Responsiveness, Assurance and Empathy" dimension had high Cronbach Alpha's value in both expectations and perceptions. Only "Responsiveness" dimension gave lower Cronbach's Alpha value in perception.

With descriptive statistics It was presented passengers' perceptions and expectations in airline services for THY and other domestic airline firms. The results of THY and other domestic airline firms were presented seperatelybecause THY's expectations' and perceptions' results were much more different than other domestic airline firms. So the differenece between them could be seen there. One-Way ANOVA test was used to calcualte the significance of the difference between expectations and perceptions. THY's passengers' expectations and perceptions were found to be close. On the other hand, for the other airline firms' passengers' expectations and perceptions had a great gap. With exception of "Empathy" dimension, it was detected that passengers' expectations and perceptions had a significant gap in all other domestic airline firms. The most important dimension in SERVQUAL scale was found to be "Reliability". Both in THY and other domestic airline firms it gave a significant 
difference between expectations and References

perceptions.

The demographics of the sample can be varied for the further research and with the larger size of the sample. This will be the issue of our further researh, which can give different results. This study can give some contribution to existing literature, based on using different kinds of airline firms. In general THY's passengers have been the sample for service quality researches in Turkey. The other domestic airline firms need to be analised about their service quality. The aim is to motivate these companies to perform better service quality and compete with THY. With this study the SERVQUAL scales for airline firms was presented. Usage of SERVQUAL in this kind of service gave also the differences between THY and other domestic airline firms were presented.
Aksoy, Ş., Atılgan, E., \& Akıncı, S. (2003). Airline services marketing by domestic and foreign firms: differences from the customers' viewpoint. Journal of Air Transport Management, 9: 343-351.

An, M., \& Noh, Y. (2009). Airline customer satisfaction and loyalty: impact of in -flight service quality. Service Business, 3: 293-307.

Berry, L.L., Parasuraman, A., \& Zeithmal, V.A. (1988). The Service-Quality Puzzle. Business Horizons, 31(5): 35-43.

Bigne, J.E., Martinez, C., Miquel, M.J., \& Andreu, L. (2003). Servqual Reliabilityand Validity in Travel Agencies. Annals of Tourism Research, 30(1): 258-262.

Chen, F.-Y., \& Chang, Y.-H. (2005). Examining Airline Service Quality From A Process Perspective. Journal Of Air Transport Management, 11: 79-87.

Gilbert, D., \& Wong, R.K.C. (2003). Passenger expectations and airline services: a

\section{МЕРЕЊЕ КВАЛИТЕТА УСЛУГЕ АЛАТОМ "SERVQUAL" ЗА РАЗЛИЧИТЕ ТУРСКЕ ВАЗДУХОПЛОВНЕ КОМПАНИЈЕ}

\section{Kenan Aydin, Seda Yildirim}

\section{Извод}

Основни циљ овог истраживања је одредити да ли постоји значајна разлика између очекивања путника о нивоу квалиттета услуге и постигнутог квалитета, за различите ваздухопловне компаније. При томе разматрани су путници различтих социо демографских карактеристика. Како би се извршило испитивање, коришћена је скала коју је предложио Parasuraman et.al (1988), са 5 димензија и 22 изјаве. Потом је овакав упитник понуђен путницима на "Sabiha Gökçen" аеродрому у Истамбулу (Турска), применом непосредног метода анкетирања. Добијени подаци су анализирани применом SPSS 16 програма. Први резултати се односе на демографске карактеристике путника у различитим ваздухопловним компанијама. Потом је вршено упоређење евентуалних разлика између очекивања и страрно постигнутог нивоа квалитета услуга.

Кључне речи: Квалитет услуга, Ваздухопловне компаније, SERVQUAL 
Hong Kong based study. Tourism 140-147.

Management, 24: 519-532.

Zeithaml, V.A., Berry, L.L., \&

Gürsoy, D., Chen, M.H., \& Kim, H.Y. Parasuraman A. (1996). The Behavioral (2005). The US airlines relativepositioning Consequences of Service Quality. Journal of based on attributes of service quality. Tourism Marketing, 60(2): 31-46.

Management, 26: 57-67.

Ishaq, M., I. (2012). Perceived Value, Service Quality, Corporate Image and Customer Loyalty: Empirical Assessment from Pakistan. Serbian Journal of Management, 7(1): 25-36.

Landrum, H., Prybutok, V., Zhang, X., \& Peak, D. (2009). Measuring IS System Service Quality With SERVQUAL Users' Perceptions of Relative Importance of The Five SERVPERF Dimensions. The International Journal of an Emerging Transdiscipline, 12: 17-35.

Liou, J.J.H., Yen, L., \& Tzeng, G.-H. (2010). Using decision rules to achieve mass customization of airline services. European Journal of Operational Research, 205(3): 680686.

Liou, J.J.H., \& Tzeng, G.-H. (2007). A non-additive model for evaluating airline service quality. Journal of Air Transport Management, 13: 131-138.

Pakdil, F., \& Aydın, Ö. (2007). Expectations And perceptions in airline services: An analysis using with weighted SERVQUAL scores. Journal of Air Transport Management, 13: 229-237.

Park, J.-W., Robertson, R., \& Wu, C.-L. (2004). The Effect of Airline Service Quality Behavioural Intentions: A Korean Case Study. Journal of Air Transport Management, 10: 435-439.

Parasuraman, A., Zeithaml, V.A., \& Berry, L.L. (1985). A Conceptual Model of Service Quality and Its Implications for Future Research. Journal of Marketing, 49(4): 41-55.

Parasuraman, A., \& Berry, L.L. (1993). More On Improving Service Quality Measurement. Journal of Retailing, 69(1): 